\title{
PELAKSANAAN VAKSINASI RABIES PADA HPR DI KENAGARIAN KAMANG MUDIAK, KABUPATEN AGAM, SUMATRA BARAT
}

\author{
Muhammad Ridwan ${ }^{1 *}$, Suzanna $^{2}$, Dedrinaldi $^{3}$, Setiawan Destika $^{3}$ \\ 1*Pendidikan Profesi Dokter Hewan, Fakultas Kedokteran Hewan, Universitas Airlangga, Surabaya \\ ${ }^{2}$ Medik Veteriner, Unit Pelaksana Teknis Puskeswan Magek, Kabupaten Agam \\ ${ }^{3}$ Paramedik Veteriner, Unit Pelaksana Teknis Puskeswan Magek, Kabupaten Agam \\ Penulis Korespodensi : muhammad.ridwan-2017@fkh.unair.ac.id
}

\begin{abstract}
Abstrak
Sumatra Barat merupakan salah satu provinsi yang memiliki tingkat kasus rabies yang cukup tinggi di Indonesia. Rabies merupakan salah satu penyakit zoonosis yang menular kepada manusia melalui hewan pembawa rabies (HPR) yang terinfeksi dan akhirnya dapat menyebabkan sakit hingga kematian. Pengabdian kepada masyarakat ini bertujuan memberikan layanan vaksinasi rabies pada HPR supaya menekan dan menurunkan penyebaran rabies serta memberikan sosialisasi bahaya dan tanggap rabies kepada masyarakat. Pengabdian dilakukan pada tanggal 3-18 Agustus 2021 di Kenagarian Kamang Mudiak, Kabupaten Agam, Sumatra Barat secara langsung dilapangan. Kegiatan pengabdian ini telah berhasil terlaksana dan mendapatkan respon yang baik dari masyarakat, HPR yang telah tervaksinasi berupa 59 ekor anjing dan 80 ekor kucing.
\end{abstract}

Kata kunci: HPR, Rabies, Vaksinasi

\section{Pendahuluan}

Sampai saat ini di Indonesia hanya 9 provinsi saja yang dinyatakan bebas dari rabies sedangkan 25 provinsi lainnya masih berusaha melakukan tindakan pencegahan dan pemberantasan rabies. Sumatra Barat merupakan salah satu provinsi yang memiliki tingkat kasus rabies yang cukup tinggi di Indonesia. Keadaan seperti ini didukung oleh kebiasaan masyarakat yang banyak memelihara anjing sebagai olahraga berburu sekaligus dalam membasmi hama babi hutan yang masuk kearea perkebunan dan persawahan masyarakat.

Rabies atau yang lebih sering dikenal dengan penyakit anjing gila merupakan penyakit yang disebabkan oleh agen infeksi virus yang bersifat akut menyerang susunan sistem saraf pusat. Virus rabies termasuk kedalam genus Lyssavirus dan family Rhabdoviridae. Virus rabies merupakan single stranded RNA yang berbentuk seperti peluru dengan ukuran $180 \times 75 \mu \mathrm{m}$ dengan sifat neurotropis, menular dan sangat ganas (Tanzil, 2014).

Penyakit rabies merupakan penyakit yang bersifat zoonosis yaitu penyakit yang dapat menular dari hewan kepada manusia maupun sebaliknya. Rabies ditularkan melalui gigitan dan jilatan air liur hewan yang positif terjangkit rabies seperti anjing, kucing, dan kera. Setiap tahunnya tercatat 50.00070.000 orang meninggal akibat rabies yang sebagian besar dijumpai pada anak anak. Manusia yang terjangkit rabies akan menampakkan gejala klinis seperti demam, nyeri, gangguan ensefalitik, gangguan paralitik dan koma yang berujung kematian (Purnamasari dan Putra, 2017).

Hewan penular rabies (HPR) di Indonesia yang utama merupakan anjing, disusul oleh kucing, kera, dan sebangsanya. Gejala klinis rabies pada HPR pada umumnya adalah demam, anoreksia, depresi, mata memerah, ganas, hipersalivasi, hydrophobia dan diakhiri kematian (Jackson, 2000).

Berbagai upaya telah dilakukan dalam pencegahan dan pengendalian rabies dengan melibatkan kerjasama dari berbagai lintas sektor seperti Kementerian Pertanian melalui Ditjen PKH dengan Kementerian Kesehatan. Upaya yang dilakukan berupa sosialisasi, pengawasan lalu lintas, dan vaksinasi terhadap HPR. Upaya tersebut juga dilaksanakan oleh UPT Puskeswan Megek melalui pengabdian kepada masyarakat di Kenagarian Kamang Mudiak dengan tujuan memberikan layanan vaksinasi terhadap HPR guna menurunkan 
dan menekan penyebaran rabies serta memberikan informasi kepada masyarakat mengenai bahaya rabies terhadap kesehatan hewan dan manusia.

\section{Metode Pelaksanaan}

Pelaksanaan kegiatan pengabdian kepada masyarakat ini dilakukan dan dikoordinasikan oleh UPT Puskeswan Magek di Kenagarian Kamang Mudiak, Kabupaten Agam, Sumatra Barat. Kegiatan dilaksanakan pada tanggal 3-18 Agustus 2021.

Metode pelaksanaan kegiatan yang digunakan adalah vaksinasi dan sosialisasi rabies secara langsung dan massal dilapangan. Pelaksanaan kegiatan dilakukan dengan dua cara yaitu: 1) Pelaksanaan vaksinasi dan sosialiasi berpusat di kantor jorong setempat 2) Pelaksanaan vaksinasi dan sosialisasi secara door to door (mengunjungi rumah masyarakat secara langsung).

Serangkaian pelaksanaan vaksinasi rabies dimulai dengan melakukan anamnesis singkat dan pemeriksaan fisik pada hewan tersebut. Apabila hewan tersebut dirasa cukup umur, sehat, dan tidak bunting dapat dilakukan divaksinasi. Setelah HPR mendapatkan suntikan, masyarakat akan diberikan sosialisai mengenai rabies dan diakhiri dengan pemberian kartu tanda bukti bahwa hewannya telah dilakukan vaksinasi rabies.

\section{Hasil dan Pembahasan}

Pelaksanaan pengabdian kepada masyarakat melalui vaksinasi terhadap HPR oleh UPT Puskeswan Magek telah berhasil dilaksanakan secara langsung dilapangan, dan diharapkan dengan adanya kegiatan ini mampu menekan dan menurunkan penyebaran rabies dan juga meningkatkan pemahaman masyarakat mengenai bahaya rabies terhadap kesehatan hewan dan manusia. Kegiatan pengabdian berhasil dilaksanakan pada tanggal 3-18 Agustus 2021. Daerah yang mendapatkan pelayanan yaitu setiap jorong yang berada di Kenagarian Kamang Mudiak seperti Bansa, Pakan Sinayan, Pauh, Padang Kunyik, Durian, Halalang, Babukik, dan Aia Tabik.

Sasaran pengabdian ini adalah masyarakat yang memiliki hewan peliharaan anjing, kucing dan kera. HPR yang telah berhasil divaksinasi kali ini berupa Anjing dan Kucing Gambar 1. Total perolehan vaksinasi rabies yaitu 59 ekor anjing dan 80 ekor kucing dengan rincian jorong Bansa 19 ekor anjing dan 16 ekor kucing, jorong Pakan Sinayan 1 ekor anjing dan 16 ekor kucing, Jorong Padang
Kunyik 6 ekor anjing dan 8 ekor kucing, Jorong Durian 18 ekor anjing dan 27 ekor kucing, Jorong Halalang 5 ekor anjing dan 1 ekor kucing, dan Jorong Aia Tabik 10 ekor anjing dan 12 ekor kucing. Data HPR yang telah berhasil dilakukan vaksinasi dapat dilihat pada tabel 1.

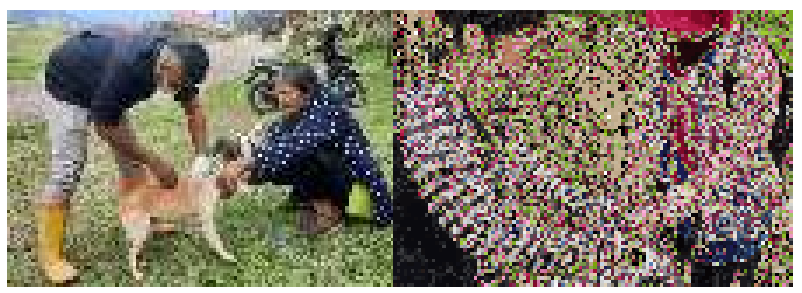

Gambar 1. Pelaksanaan vaksinasi rabies pada anjing dan kucing

Tabel 1. Data HPR yang berhasil dilakukan vaksinasi

\begin{tabular}{ccc}
\hline $\begin{array}{c}\text { Jorong di Kenagarian } \\
\text { Kamang Mudiak }\end{array}$ & $\begin{array}{c}\text { Anjing } \\
\text { (Ekor) }\end{array}$ & $\begin{array}{c}\text { Kucing } \\
\text { (Ekor) }\end{array}$ \\
\hline Bansa & 19 & 16 \\
Pakan Sinayan & 1 & 16 \\
Padang Kunyik & 6 & 8 \\
Durian & 18 & 27 \\
Halalang & 5 & 1 \\
Aia Tabik & 10 & 12 \\
\hline Total & 59 & 80 \\
\hline
\end{tabular}

Kegiatan vaksinasi rabies pada HPR disambut baik oleh masyarakat, mulai dari kalangan tua hingga anak-anak yang membawa hewan peliharaan mereka untuk divaksin. Sebagin besar masyarakat sudah paham mengenai pentingnya vaksinasi rabies pada HPR, walaupun tidak sedikit masyarakat yang juga menolaknya. Masyarakat yang menolak hewannya untuk divaksinasi biasaya dengan alasan baru selesai divaksin, sakit, dan juga ada yang takut hewannya mengalami penurunan performa saat berburu pasca vaksinasi.

Vaksin rabies yang digunakan dalam pengabdian ini berupa vaksin Nobivac ${ }^{\circledR}$ dan Rabisin ${ }^{\circledR}$ dengan dosis $1 \mathrm{ml}$ per ekor, vaksin ini sering digunakan dalam program vaksinasi HPR. Kedua vaksin ini mengandung virus inaktif dengan cara pemakaian injeksi subcutan (SC) dan intramuscular (IM). Kegiatan vaksinasi ditujukan dalam menjaga kekebalan kelompok (herd immunity) dengan mempertahankan cakupan titer antibody protektif lebih dari $70 \%$ sesuai anjuran OIE, selain itu pengendalian HPR terutama pengawasan terhadap HPR liar dan lalulintas HPR 
juga perlu diperhatikan (Inanusantri, 2019). Namun apabila pelaksanaan kegiatan ini tidak dilakukan secara optimal tidak akan memberikan hasil yang banyak (Bili, 2014). Rabies memiliki efek negatif yang sangat banyak apabila suatu daerah tersebut sudah tertular seperti menimbulkan dampak psikologis bagi penderita berupa kegelisahan, kekhawatiran, dan juga rasa yang tidak nyaman. Selain itu juga menimbulkan kerugian ekonomi pada suatu daerah karena tingginya biaya pemeriksaan dan pengendaliannya (Cahyana dkk., 2021).

Setelah dilaksanakan vaksinasi ini diharapkan muncul titer antibody protektif pada HPR yang telah divaksinasi. Tingkat titer antibody protektif yang dihasilkan dapat dipengaruhi oleh kualitas vaksin yang digunakan dan juga volume dosis yang dianjurkan (Sudarmayasa dkk., 2020).

Pemberian sosialisasi mengenai informasi seputar rabies dilakukan setelah perlakuan injeksi vaksin rabies terhadap HPR, sosialisasi dianggap penting karena memberikan antisipasi dan kewaspadaan masyarakat terhadap rabies. Informasi yang dapat diberikan saat sosialisasi dapat berupa: cara penularan rabies, cara pengobatan rabies, dan cara pencegahan rabies (Dilago, 2019).

\section{Kesimpulan}

Berdasarkan hasil kegiatan ini, disimpulkan bahwa vaksinasi dan sosialisasi rabies terhadap hewan pembawa rabies (HPR) berhasil dilaksanakan dan mendapatkan respon yang bagus dari masyarakat. Kegiatan ini diharapkan mampu menekan dan menurunkan penyebaran tingkat rabies.

\section{Daftar Pustaka}

Bili, F. A. L. (2014). Serosurveilens Pascavaksinasi Rabies Tahun 2014 di Wilayah Kerta UPT Veteriner Nusa Tenggara Timur. Jurnal Kajian Veteriner. 2(2), 119-126.

Cahyana, I. P. A. T, M. Pharmawati dan I. Narayani. (2021). Deteksi Level Antibodi pada Serum Darah Anjing Kintamani Pasca Vaksinasi Rabies dengan Direct ELISA. Metamorfosa: Journal of Biological Sciences. 8(1), 172-177.

Dilago, Z. (2019). Penyuluhan dan Pelaksanaan Vaksinasi Rabies di Desa Tagalaya Kecamatan Tobelo. Jurnal Pengabdian Masyarakat: Darma Bakti Teuku Umar. 1(1), 93-100.

Inanusantri. (2019). Monitoring Antibodi HPR Paca Vaksinasi Rabies di DKI Jakarta 2013-2015. Prosiding PPIS 2019-Semarang. 361-370.

Jackson, A. C. (2000). Rabies. The Canadian Journal of Neurological Sciences. 27(4), 278-282.

Purnamasari, L dan K. A. D. Putra. (2017). Pengendalian dan Manajemen Rabies pada Manusia di Area Endemik. Continuing Professional Development. 44(1), 66-69.

Sudarmayasa, I. N, I. B. K. Suardana dan I. N Suartha. (2020). Titer Antibodi Anjing Lokal Enam Bulan Pasca Vaksinasi Rabies. Buletin Veteriner Udayana. 12(1), 50-54.

Tanzil, K. (2014). Penyakit Rabies dan Penata Lakasanaannya. E-Journal WIDYA Kesehatan dan Lingkungan. 1(1), 61-67. 